\title{
液体が関与するプラズマ材料プロセシング
}

\author{
白 藤立 ${ }^{1,2}, *$ \\ ${ }^{1}$ 大阪市立大学大学院工学研究科電子情報系専攻 矛 558-8585 大阪府大阪市住吉区杉本 3-3-138 \\ 2 東京理科大学総合研究院ウォーターフロンティアサイエンス \& テクノロジー研究センター \\ 恶162-8601 東京都新宿区神楽坂 1-3
}

（2017 年 7 月 3 日受付；2017 年 11 月 23 日掲載決定）

\section{Plasma Materials Processing Involving Liquid}

\author{
Tatsuru SHIRAFUJI ${ }^{1,2, *}$ \\ ${ }^{1}$ Department of Physical Electronics and Informatics, Osaka City University, \\ 3-3-138 Sugimoto, Sumiyoshi-ku, Osaka-shi, Osaka 558-8585, Japan \\ ${ }^{2}$ Water Frontier Science \& Technology Research Center (W-FST), Research Institute for Science \& Technology, \\ Tokyo University of Science, 1-3 Kagurazaka, Shinjuku-ku, Tokyo 162-8601, Japan
}

(Received July 3, 2017 ; Accepted November 23, 2017)

\begin{abstract}
In materials processing using plasma in contact with liquid, plasma plays an important role as a trigger to promote primary processes at the plasma/liquid interface. However, direct effects such as radicals from plasma vanish after traveling a few or a few $10 \mathrm{~nm}$ from the plasma/liquid interface. The rest of the processes in liquid proceed only deep inside the liquid where the direct effects of plasma are no longer expected. This situation can be regarded as robustness in the process. However, at the same time, it has a negative aspect of poor controllability by plasma. In other words, the factor of "the unique to plasma" governs only the limited part of a whole process. In this paper, we survey recent research activities on materials processing using plasma in contact with liquid from the view point mentioned above, and discuss why we use plasma.
\end{abstract}

KEYWORDS : plasma, liquid, interface, material, processing

\section{1.は じめ に}

適度な減圧条件下でプラズマを生成すると, 電場で加 速される電子は数十万度の高温になる。この高温（高エ ネルギー）の電子は, その減圧雲囲気に存在する分子を 分解することが可能であり, その分子由来の活性な化学 種を生成する。この活性化学種が様々な材料プロセスに 利用されている。この活性種がプロセス対象物（多くの 場合, 固体表面) に化学吸着したときに, 揮発性の物質 を形成すると, プロセス対象物から何かを除去するとい うプロセスになる。典型的な例がアッシングやエッチン グプロセスである。逆に, そのときの温度では揮発しな い場合には薄膜堆積となる。

*E-mail : sirafuji@elec.eng.osaka-cu.ac.jp
こうした材料プロセスを実施する際に，雲囲気の温度 はそのプロセスの実用性を左右する重要な因子となる。 活性種の生成は, 分子の熱解離でも可能であるが, 多く の多原子分子の場合, 分子の解離のためには, 数百度か ら千度以上の温度が必要となる。プロセス対象物がその 温度に耐えることができるのであれば, 熱解離を用いる ことができるが，プロセス対象物が紙やプラスチック， 更には液体や生体の場合には，そのような高温に曝すわ けにはいかない。

滅圧下でプラズマを生成することの大きなメリット は, 雲囲気の分子の温度が, 電子の温度よりも低く, 場 合によっては室温近辺に抑えることができる点にある。 これは，電子の質量が分子の質量よりも極めて小さいた めに, 一回の衝突で電子から分子に与えられる並進エネ ルギーが極めて小さいこと, 並びに, その衝突回数が減 


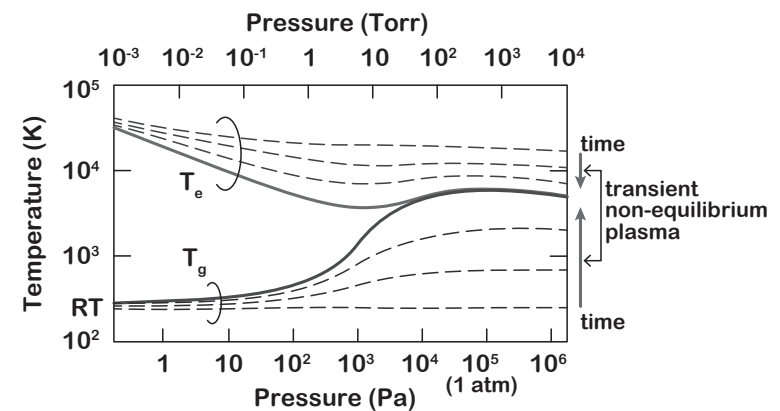

Fig. 1. Steady state (solid line) of pressure dependence of electron temperature and gas temperature, and conceptually drawn transition states.

圧であるために少ない，ということに起因する。減圧プ ラズマは，このような「低温」という特徵を有するた め，様々な材料プロセスに応用されてきた。

一方, 圧力が高くなり衝突頻度が高くなると, 電子が 分子に与える並進エネルギーの積算値が大きくなる。こ のため, 圧力が高くなると, Fig. 1 に示すように, ガス 温度が高くなるとともに，電子温度が低下する1)。十分 な衝突回数を経た定常状態の大気圧の場合には, 電子と 分子の並進エネルギーの授受が平衡状態に達し, 電子と 分子の温度が等しい熱平衡プラズマとなる。一般に, 熱 平衡プラズマは, その温度が千度以上の高温プラズマと なるため, その用途も高温処理を目的とした溶接などに なる。

衝突頻度の高い大気圧であっても, 衝突の積算回数を 小さくすれば，上記のようなことが抑制され，低ガス温 度を保つことが可能となる。具体的には, 非平衡の初期 状態から熱平衡に到達する前に, 電圧印加を止めればよ い。古くからある誘電体バリア放電（DBD）と呼ばれ る方式は，電極に誘電体を用いることによって，上記の 機構を自動的に実現したものである。即ち，生成したプ ラズマ中の電荷が誘電体に蓄積することにより, 印加し た電圧とは逆向きの電圧が誘電体に発生し, 電極間の電 圧を放電維持電圧以下まで下げる。これだけでは一回の 放電しかできないが，電極間の電圧を交流にすれば，持 続的に放電を維持することが可能となる。しかし，この DBD における放電ギャップ間の電圧印加時間は，プラ ズマから誘電体に蓄積される電荷量に支配されている。 そのため，その時間を緻密に制御することが困難とな る。即ち，DBD は，使うのは容易だが，自在に操るの が難しいという性質を有している。

一方, 近年のパルス電圧源の発展にともない, 極短パ ルスの電圧でプラズマを自在に生成できるようになっ た。これにより，DBD に頼ることなく，ガス温度を低
温に保った大気圧プラズマの特性を自在に操れるように なったと言える。低温大気圧プラズマは古くから存在し ていたが，本格的に産業応用が検討されるようになった のは，こうした電源の入手容易性が向上したためとも言 える。こうした背景もあり，現在では，プラズマと接す る媒質として，減圧環境に持ち込むことのできない液体 も低温プラズマ材料プロセスの適用範囲に入れて検討さ れるようになり，ソリューションプラズマ (SP) 材料 プロセシングと呼ばれている2)。更に，減圧環境に曝す ことのできない生物までもがプラズマプロセスの対象と なり, プラズマ医療やプラズマ農業といった新領域が開 拓されている。

但し，プラズマからの活性種供給に代表される直接的 な効果は，それが高い反応性を有すること，及びそれが 注入される媒質が密度媒質であることにより, 液面直下 の極薄領域（おおよそ数 $\mathrm{nm}$ から数十 $\mathrm{nm}$ の梁さ）にし か影響を及ほささない。それよりも深い液中の反応には, プラズマからの直接的効果は残念ながら全く関与しな い。しかし, 筆者の研究も含めて, 液体が関与するプラ ズマプロセスのほとんどはバルク液体中の反応を利用し たものとなっている。このような状況下に扔いて, プラ ズマを使うことの意義は, 仮にプラズマが単なるトリガ 一としての機能しか持たないとしても，それによって得 られる結果が非プラズマ系では得られない，ということ に尽きるであろう。もしくは，プラズマの存在価值を明 確にするために，プラズマからの直接的な効果が及ぶ液 界面近傍だけを使う，という視点もあり得る。

本稿では，液体が関与するプラズマ材料プロセシング を上記のような観点で概観し，そこにプラズマが関与す ることの意義は何か，という点に注目して議論する。

\section{2. 液中・液面上放電の歴史}

Faraday 暗部を発見した Faraday の実験ノートを紐解 くと ${ }^{3)}, 1836$ 年の 6 月 21 日に Faraday 暗部を発見したこ とが，実験ノート第 3 巻 19 頁に記録されている。その 数日後の 1836 年 7 月 4 日の実験ノート (第 3 巻 54 頁) を見ると Fig. 2 のような実験がなされたことが記録され ている。Faraday は, Faraday 暗部発見の数日後に, 現在 ソリューションプラズマと言われている実験系を試して いたことがわかる。その記録内容は, 液体の種類や印加 電圧の大きさによって, 通電, 絶縁, スパーク放電が起 こるという初歩的なもので，現在のように高度なことは なされていない。しかし，全く未知の対象に取り組む Faraday の姿勢は，学ぶところがあると思われる。

その後の 1887 年には, Gubkin が液面上放電による 銀，白金， $\mathrm{ZnO}$ の薄膜を液面上で形成しているが4)，周 


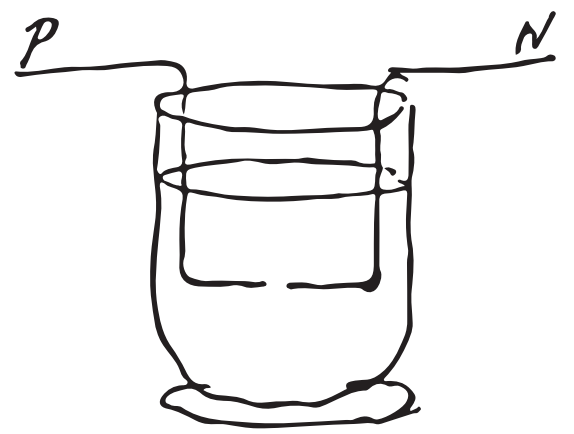

Fig. 2. A schematic diagram of the SP experiment conducted by Faraday on July 4, 1836, which is depicted in his notebook.

囲の研究者がこの薄膜形成に興味を持たなかったのか, その後の液体関与プラズマの登場は 1958 年の Hickling 等によるグロー放電電解まで待つことになる。 Hickling 等は，化学の実験で利用される $\mathrm{H}$ 管の片方の電極と液 面の間で放電をさせ，プラズマ電極を用いた電気化学反 応を誘発させている 5,6$) 。$ Mezei 等は，この方式のプラズ マ電極側だけに注目し, 発光分光による液体の分析に使 えることを示した ${ }^{70)}$ 。近年になって，同様の取り組み が Richmonds 等や白井等によってなされており, 磁性材 料の合成やコアシェルナノ粒子の合成などの新たな知見 が得られている ${ }^{11 \sim 13)}$ 。これらは「合成」に関する研究で あったが, 1968 年には, 東京大学の倉藤等により, ス パーク援用化学彫刻という液中での電気化学的なエッチ ングが報告されている ${ }^{14,15)}$

こうした過去の黎明期がありながら，最近になってよ うやく液体が関与するプラズマが注目されるようになっ たのは，冒頭に述べたパルス電源の発展によるものであ ろうと筆者は推測している。

\section{3. マイクロ・ナノフィラーの修飾}

炭素瀻維強化プラスチックに代表されるポリマー複合 材料は, ポリマーの持つ軽量性を維持しながら機械的強 度等が向上した材料となるため, 様々な分野で利用され ている ${ }^{16)}$ 。しい，ポリマー中に添加されたフィラーの 分散性が悪いと機械的特性も不十分となる ${ }^{17) 。 そ の た ~}$ め, 混練時の分散性向上や親和性向上のために, シラン 系カップリング剂を用いたフィラー表面の修飾などが行 われている18)。しかし，この手法では，カップリング鼡 がポリマー側に流出し, 形成物の着色や耐熱水性の低下 などを招く。そのため,こうした副作用を伴う薬凨を使 わないフィラー表面修飾法が求められている。本節で は, 液体と気相とで構成される SP プロセス応用の一つ として, 複合材料形成用フィラーとしてのカーボンナノ ボール（CNB）の表面処理の効果について紹介する ${ }^{19) 。 ~}$
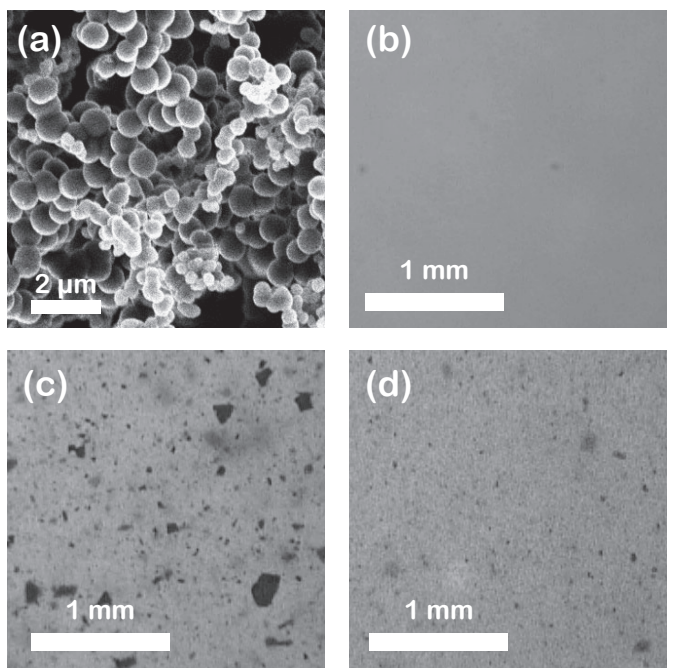

Fig. 3. (a) Scanning electron micrograph of CNBs used as a filler, and transmission micrographs of the composites made from (b) additive-free PA6, (c) PA6 with untreated CNBs, and (d) PA6 with SP treated CNBs.

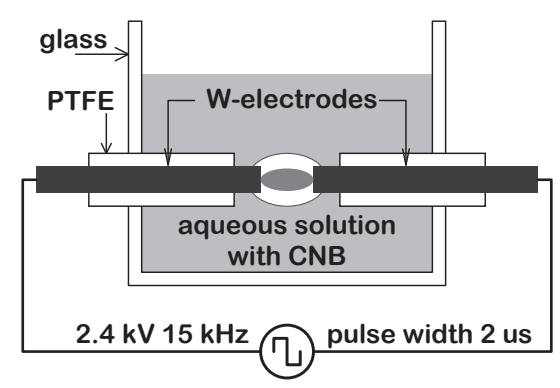

Fig. 4. A schematic diagram of the reactor for SP processing.

処理対象の CNB は, 熱化学気相法によって合成され ており，その概観は Fig. 3 (a) に示す通りである。こ の CNB の表面処理は, Fig. 4 に示すような SP 処理装置 で行う。水溶液は, CNB がある程度水となじむように $20 \%$ のタノール水溶液となっている。また, 放電し 易くするために $\mathrm{KCl}$ によって導電率が $300 \mu \mathrm{S} / \mathrm{cm}$ に調 製されている。水中に挿入されたタングステンの電極間 隔は $0.3 \mathrm{~mm}$ であり, その電極間に周波数 $15 \mathrm{kHz}$, パル ス幅 $2 \mu \mathrm{s}$, 電圧 $2.4 \mathrm{kV}$ のバイポーラパルス電圧（栗田 製作所 MPS-06K-01C 特殊) を印加する。2 時間の放電 後, 処理溶液を $393 \mathrm{~K}$ で乾燥することにより粉状の SP 処理 CNB が得られる。

Fig. 5 (a) と5（b）は，それぞれ，処理前と处理後 の CNB を水に溶かした様子である。無処理の CNB は 水に分散しないが, 処理後の CNB は水に分散している。

Fig. 3 (c) と 3 (d) は無処理と SP 处理後の CNB を ポリアミド 6 (PA6) と混練し, 押出成形によって得た 板状複合材料の透過顕微鏡写真である。Fig. 3 (b) は比 


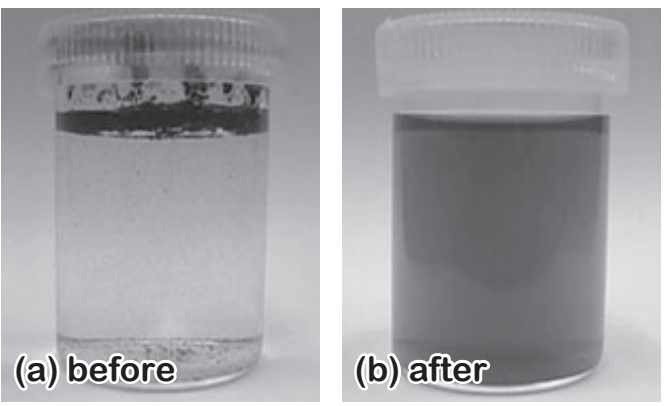

Fig. 5. Dispersion characteristics of $\mathrm{CNBs}$ in the water before and after SP processing.

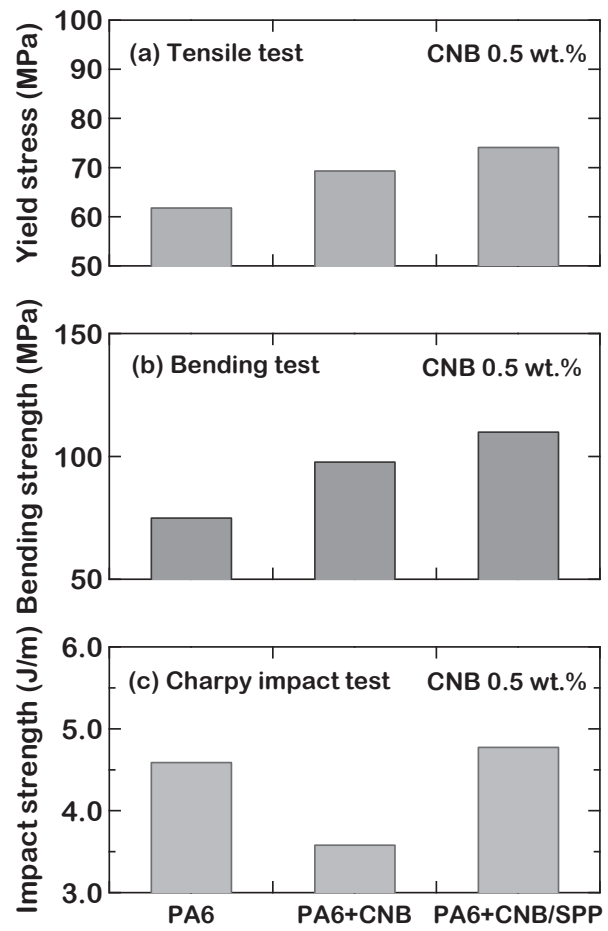

Fig. 6. (a) tensile strength, (b) bending strength, and (c) impact strength of the additive-free PA6, PA6 with untreated CNBs, and CNBs with SP treated CNBs.

較のために撮影した無添加のPA6 の写真である。無処 理 CNB は凝集しているが，CNB を SP 処理することに より複合材料中での分散性が向上している。

Fig. 6 は，無添加のPA6，無処理 CNB を添加した PA6，および SP 処理 CNB を添加したPA6の引っ張り 強度, 曲げ強度, および衝撃強度を評価した結果であ る。無処理 CNB を添加するだけでも, 引っ張り強度と 曲げ強度は向上するが，衝撃強度は劣化する。これは， CNB と母材の PA6 との親和性が無いために, クラック の原因となる箅所が存在するためである。一方，無処理 $\mathrm{CNB}$ を添加した場合と比較すると, SP 処理 CNB を添 加した場合には, 引っ張り強度と曲げ強度の若干の向上
が見られる。その向上率は無添加 PA6 に無処理 CNB を 添加したときほど顕著ではないが，衝撃強度は元々の PA6 と同程度にまで回復している。これは, SP 処理に よってPA6 の中における CNB の親和性が向上したため である。この起源は, SP 処理によって CNB 表面に $-\mathrm{OH},-\mathrm{COH},-\mathrm{COOH}$ 等の親水基が形成されたことにあ るとされている。

CNB よりも大きさの小さい多層カーボンナノチュー ブの表面をアミノ化する目的でアンモニア水中 SP 処理 を行った例も報告されている200。残念ながら，アミノ化 ではなくニトロ化が生じるが，得られた複合材料は CNB 添加の場合よりも引っ張り強度が高い。なお，同 様のプロセスは, 水溶液中の熱的な化学反応を用いても 可能である $\mathrm{SOCl}_{2}$ ，エチレンジアミンなどの薬剤を添加し，かつ数 日間加熱し続けなければならない。SP の場合には，こ うした複数の薬剤を投入する必要がなく，かつ数時間で 同等の処理が可能となる。このことから，短納期を要求 される場合に，SP 処理を採用するメリットを享受でき ると考えられる。

\section{4. 水中有機分子分解}

環境応用技術としての SP 処理に関する研究も数多く 取り組まれている。これは水溶液中でプラズマを発生さ せると, 強力な酸化剂である $\mathrm{OH}$ ラジカルが生成され, オゾンや過酸化水素では分解できない有機物を分解でき

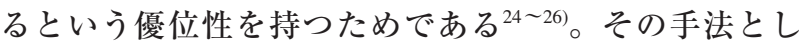
て, Fig. 4 に示すような水中放電の他に, 液面上の放電 や強制的に気泡を導入した気泡内放電など，様々な放電 様式が提案されている ${ }^{27,28)}$ 。しかし，どの手法の場合 も，処理対象である液体のボリュームに対して，液体と プラズマとの接触面積があまりにも小さいという問題点 があった。本節では，筆者らが提案した三次元集積化マ イクロソリューションプラズマ（3D IMSP）とその処理 効率について紹介する ${ }^{29,30)}$ 。

なお，残念ながら，まだ当該放電方式による難分解性 物質の分解には着手していないため, 多くの研究機関に て分解効率を比較するときに利用されているメチレンブ ルーの分解効率を題材にして述べる。

Fig. 7 (a) と 7（b）は，それぞれ，3D IMSPリアク ターの概念図と実機動作中の写真である。十字型のガラ 又管の中に誘電体の連続多孔体が内包されており，その 中心部には高電圧電極が埋め达まれている。この中心電 極から放電用ガスが放出されることにより，多孔体の中 心から外周に向かって液体と放電用ガスの気泡の混合媒 質が流れる。ガラス管の外壁にはメッシュ状の接地電極 


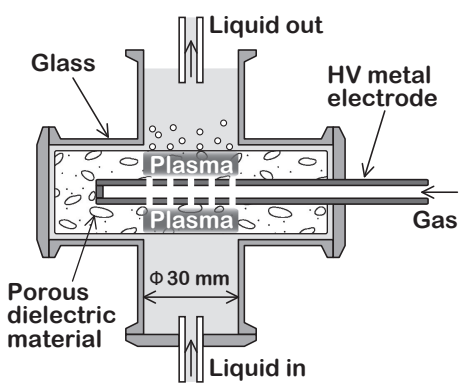

(a)

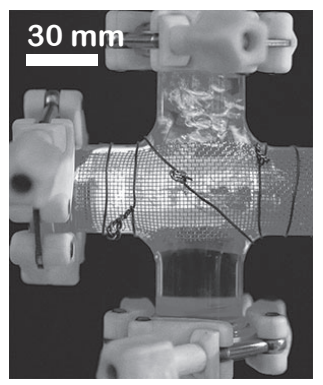

(b)
Fig. 7. (a) A schematic diagram and (b) a photograph of a 3D IMSP reactor.

が設けてあり, 中心電極との間に高電圧パルス電圧が印 加される。これにより, 液体と接している気泡内で放電 が起こる。多孔質体の空孔径によって気泡サイズが小さ く抑えられており, 小さい複数の泡が液体と接する環境 が形成されている。これにより，プラズマ/液界面の面 積に対する液体体積の比率を実効的に下げている。発光 分光を行ったところ, $\mathrm{OH}$ の発光が観測されており, 気 泡内には放電ガスだけではなく水蒸気が含まれているこ とを確認している。なお, Fig. 4 に示した従来の SPの 場合には，ジュール加熱による気泡生成のための電力が 別途必要となるのに対し, 3D IMSP の場合には, 気泡 が外部から供給されるため, 消費される電力は理想的に は放電用のみとなる。

Fig. 8 は, 波長 $665 \mathrm{~nm}$ 近傍に現れるメチレンブルー の吸光度スペクトルの SP 処理時間依存性を示した図で

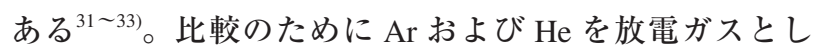
て用いた 3D IMSP の場合と, Fig. 4 に示した従来の SP を用いた場合の結果を示した。同図から, 従来のSP と 比べると 3D IMSP を用いた方が短時間で吸光度が減少 していることがわかる。

なお，3D IMSP と従来の SP が全く異なる放電様式で

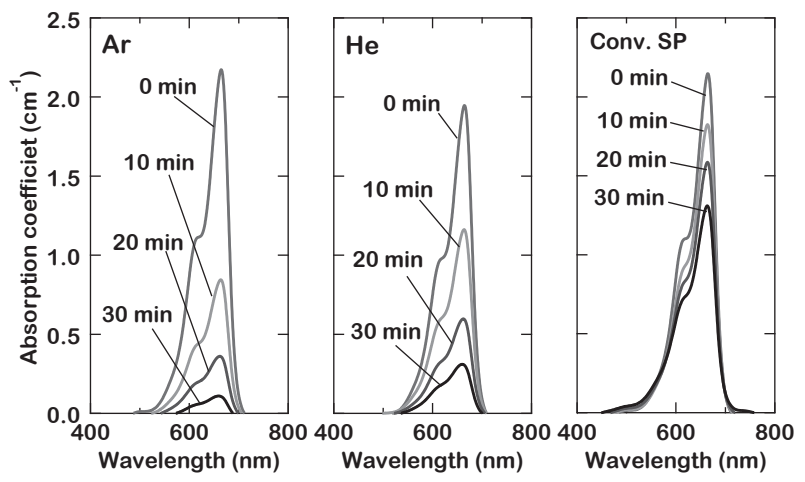

Fig. 8. SP-treatment time dependence of absorbance spectra of methylene blue aqueous solution.
Table 1. Degradation efficiency of methylene blue.

\begin{tabular}{cccc}
\hline & $\mathrm{Ar}$ & $\mathrm{He}$ & Conv. SP \\
\hline$\Delta \mathrm{MB}_{10 \min }(\mathrm{mg})$ & 0.40 & 0.23 & 0.048 \\
$E(\mathrm{Wh})$ & 5.4 & 5.6 & 15 \\
$\eta(\mathrm{mg} / \mathrm{Wh})$ & 0.073 & 0.042 & 0.0032 \\
\hline
\end{tabular}

あることから，消費電力の帯域を全く同じに揃えること が困難であったため，両者を適切に比較するために，最 初の 10 分間の吸光度の減少量から割り出されるメチレ ンブルーの分解量をその 10 分間の消費電力量で規格化 した分解効率で比較した。その結果を Table 1 に示す。 電力量は, オシロスコープによって電圧・電流波形を計 測し，それらの積を 10 分間だけ積分して求めたもので ある。従来の OD SP の効率と比較すると，3D IMSP の 効率は, 約 1 茠高い分解効率となっている。このこと は, メチレンブルーの分解の担い手が液体に作用する効 率が, 従来の OD SP よりも 3D IMSP の方が高いことを 示している。3D IMSP はジュール加熱による気泡生成 が不要であることから, 省電力になったことも効率が高 くなった原因の一つであるが，筆者はもう一つ重要な効 果が潜んでいると考えている。

冒頭で述べたように，プラズマの効果を際立たせよう とするならば，プラズマ処理の対象物を液体の表面近傍 だけ，もしくは極めて薄い液膜にするのがよいはずであ る。ここで紹介した 3 D IMSP の場合にも，放電する気 泡の周囲の液体の厚みが全て極薄になるように設計すれ ば，プラズマの効果が際立つと予想している。現在の装 置では，この制御が液体と気体の流れに任せきりとなっ ており，気泡の周囲の液体環境が必ずしもそのようにな っていないが, 部分的にはそのような領域もできている と考えており，それが処理効率が 1 桁高くなった原因の 一つではないかと考えている。

なお，3D IMSP において，放電ガスとして $\mathrm{Ar} と \mathrm{He}$ を用いた場合を比較すると， He を用いた場合の方が効 率が悪い。一般に, 同じ投入電力で $\mathrm{Ar}$ と $\mathrm{He}$ のプラズ マを比較すると, $\mathrm{Ar}$ の方が電子密度が高い。また, $\mathrm{Ar}$ の準安定励起原子が $\mathrm{H}_{2} \mathrm{O}$ を分解し $\mathrm{OH}$ ラジカルを生成 するのに対し，水のイオン化エネルギーを超える準位に ある He の準安定励起原子の場合にはそれが期待できな

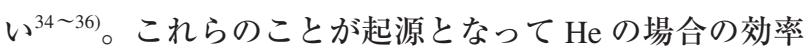
が悪いと考えている。また，He は高価なガスであるこ とから，Arの方が優位であることは実用的にも都合が よい。なお，SPを用いたメチレンブルーの分解反応過 程については, 詳しい報告例があまり無いが, 光触媒を 用いた場合の分解過程とよく似た分解過程となっている

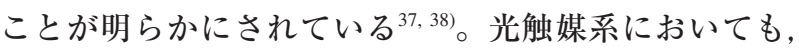


$\mathrm{SP}$ の場合と同様に, 分解の主たる担い手は $\mathrm{OH}$ ラジカ ルとされている ${ }^{39,40)}$ 。光触媒系と比較したときの SP の メリットの一つとして, 導光が不要であるという点を挙 げることができる。なお，化学の分野においてよく知ら れている $\mathrm{OH}$ ラジカル生成法として, Fenton 反応を利用 したものがある ${ }^{41 \sim 43)}$ 。電気や光を必要とする SP や光触 媒に対して，Fenton 反応はそれらを必要としない，とい う優位点を有する。しかし，触媒である鉄がへドロ化す るという難点を有する。

\section{5. 大腸菌殺菌, 過酸化水素生成}

水中有機物分解が可能であるならば，滅菌，殺菌，除 菌などの応用も可能となる。筆者らは, 大容量化可能な 3D IMSP の可能性を調べるために，水処理プロセスの 一つとして大腸菌の殺菌を試みた。大腸菌は, 浸透圧に よって容易に死滅するため, 大腸菌が死滅しない 5 vol.\%のグリセロール水溶液中の大腸菌を 3D IMSP に よって処理した。印加電圧は $5 \mathrm{kV}, 20 \mathrm{kHz}$ ，パルス幅 2 us の矩形波であり，放電用ガスは $\mathrm{Ar}$ とした。水温は冷 媒中を循環させて $20 \sim 30^{\circ} \mathrm{C}$ に保った。水溶液中の大腸 菌濃度は, $8 \times 10^{6} \mathrm{cells} / \mathrm{mL}$ とした。

Fig. 9 （a）は， 3 分処理前後の水溶液から培養した大 腸菌のコロニー形成の状態である。3 分の処理で培養不 可能な状態にまで死滅していることがわかる。なお, Control は，無放電で循環のみを行った結果であり，こ の場合には，死滅していない。近年，菌を含む液体を直 接プラズマ処理しなくても，一旦プラズマ処理水 （PTW）やプラズマ処理培地（PAM）を製造し，それを 菌に作用させることにより殺菌もしくは滅菌が可能であ

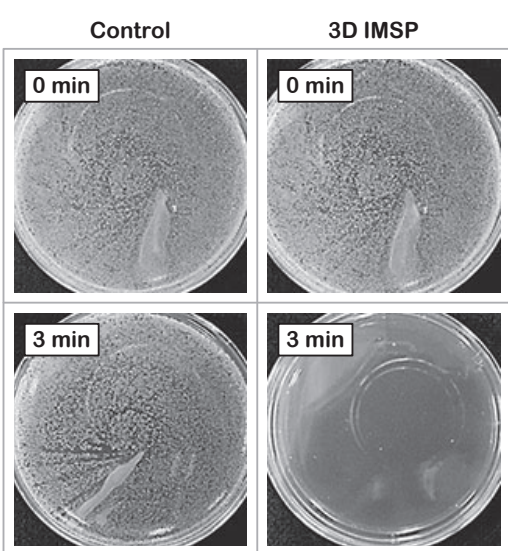

(a)

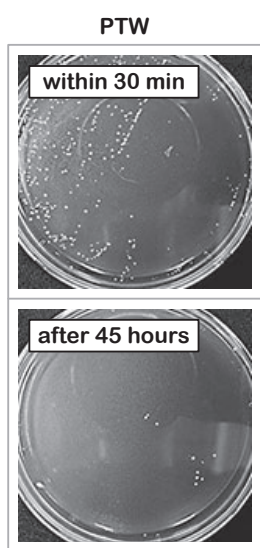

(b)
Fig. 9. (a) E. coli colonies cultured from E. coli-containing aqueous solution after circulating without discharge plasma (control) and with 3D IMSP. (b) E. coli colonies cultured after adding 3D IMSP-treated water.

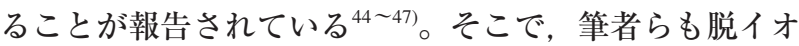
ン水を 6 分間処理した PTW 調製し，そのPTWを使 った 5 vol. \% グリセロール水溶液に大腸菌を導入する害 験を行った。その際，PTW 製造後 30 分以内に使用した 場合と，24 時間室温放置した後に使用した場合を比較 した。その結果を Fig. 9 （b）に示す。同図から，直接 プラズマ处理をしなくとも，PTW でも殺菌が可能であ ることがわかる。しかし，その後の調查の結果，筆者ら のPTW に生成された過酸化水素と同じ濃度の過酸化水 素を添加した場合でも，ほぼ同様のことが起こった。他 で報告されている PTW やPAM は，過酸化水素等の酸 化剂だけでは説明できない殺菌力や有機物分解能力が観 測されており，プラズマ独自の効果ではないかと考えら

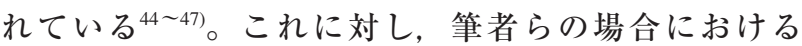
PTW の効果は，残念ながら，他で報告されているよう な PTW やPAM のそれとは異なり，単なる過酸化水素 水による効果であることが明らかとなった。

なお，細胞が死ぬ形式には，ネクローシスとアポトー シスがあることが判っておりり ${ }^{48,49)}$ ，前者は細胞組織の受 動的な破壊であり，多くの場合，細胞壁の破壊などが伴 う。後者は, 細胞自身の能動的な自殺であり, 細胞内で それが生きるために伝達されているシグナルに異常をき たすことが原因とされている。本研究に扔ける細胞死が どちらに属するのかは現時点では未解明であるが，過酸 化水素による細胞死は，多くの場合，酸化ストレスによ

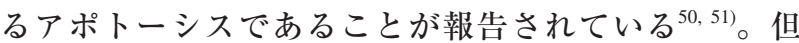
し，直接プラズマ処理をした場合には，UV 光等による DNA の損傷を起源とするアポトーシスが起こる可能性 や $^{52 \sim 54)}$ ，比較的強いエネルギーのプラズマで处理した際 に観測されるネクローシス ${ }^{55,56)}$ が起こっている可能性が ある。

今回のように，殺菌の起源が過酸化水素であるとなる と，一般には，プラズマの存在価值が全く無いと判断さ れることが多い。なぜなら，面倒なプラズマを用いなく ても，過酸化水素を買ってくればよいからである。しか し，過酸化水素水を生成するためには，アントラキノン 法と呼ばれるプラントレベルの施設が必要となる57)。そ うした施設が近隣に無い場合には，遠方から過酸化水素 を輸送する必要があり，場合によっては海外から輸入す ることになる。これに対し，電気と水さえあればよい本 方式は，太陽電池等を独立電源としたオンサイト・オン デマンド型の過酸化水素生成法となっていると考えら れ，その生成効率が向上できれば，実用可能ではないか と考えている。なお，最近報告された Liu 等による DC 放電方式の $1.74 \mathrm{mg} / \mathrm{Wh}$ と比較すると ${ }^{58)}$, 残念ながら, 現時点の筆者らの効率は $0.56 \mathrm{mg} / \mathrm{Wh}$ という劣った結果 
となっており，生成効率の向上が望まれる。

\section{6. マイクロバブルの援用}

3D IMSP は, 従来の点放電型の SP と比較すると, メ チレンブルーの分解効率が約一桁高いという特徴をもっ ている。しかし，3D IMSP は，一つの気泡の周囲が, 全体的, もしくは部分的に水で覆われるため, 水の導電 率が高くなると, 気泡に印加されるべき電圧が導電性の 水によって短絡されることになる。従って, 高導電率の 水を処理対象としたときに放電開始と維持をすることが 困難となる ${ }^{59)}$ 。これは，3D IMSP を適用できる水の種類 を限定するものとなっていた。例えば，今中等によって 発見された超好熱菌は, 廃裹バイオマスを食料とした代 謝時に水素を連続発生することが知られているが，同時 に自身を死滅させる要因となる酢酸も発生する ${ }^{60,61)}$ 。こ の菌は海水中に存在するため, 導電率が海水程度（約 $50 \mathrm{mS} / \mathrm{cm})$ の液体中で難分解性物質の代表的物質とし て知られている酢酸を分解する必要がある。残念ながら 現時点では, この導電率の液体を用いて3D IMSP を動 作させることは不可能である。

そこで筆者らは，3D IMSP が適用できる導電率の範 囲をより広範囲にするために, 近年入手が容易となった マイクロバブルの援用を検討した。マイクロバブルの気 泡は絶縁性の気体であることから，マイクロバブルを処 理対象の水に混在させることにより, 水の導電率を実効 的に下げる効果が期待される。用いた実験装置は, 先述 の 3D IMSP 液体循環系にマイクロバブル発生器（Hack UFB FB11）を設けた構造になっている。なお，現時点 では, マイクロバブルの密度や径などの詳細な特性は明 らかにはなっていないが, 処理対象の液体をマイクロバ ブル発生器に通過させることにより白濁した液体とな る。

Fig. 10 は異なる導電率の水を対象としたときに, 、 イクロバブルの有無が3D IMSP の放電状態にどのよう な影響を及ぼすかを観察した結果である。マイクロバブ ルが無い従来の 3D IMSP の場合には, 水の導電率が

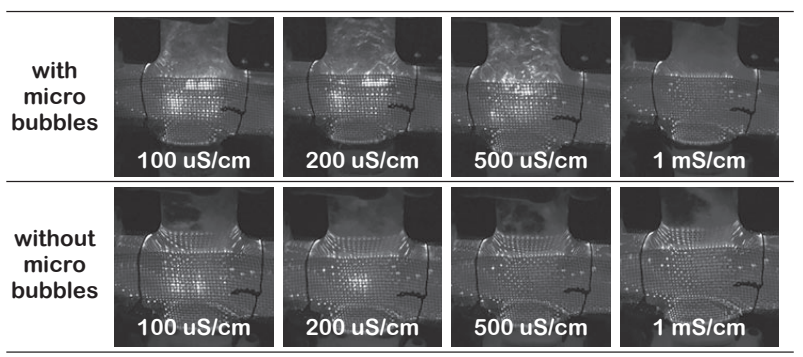

Fig. 10. Discharge characteristics in a 3D IMSP reactor with and without micro bubbles.

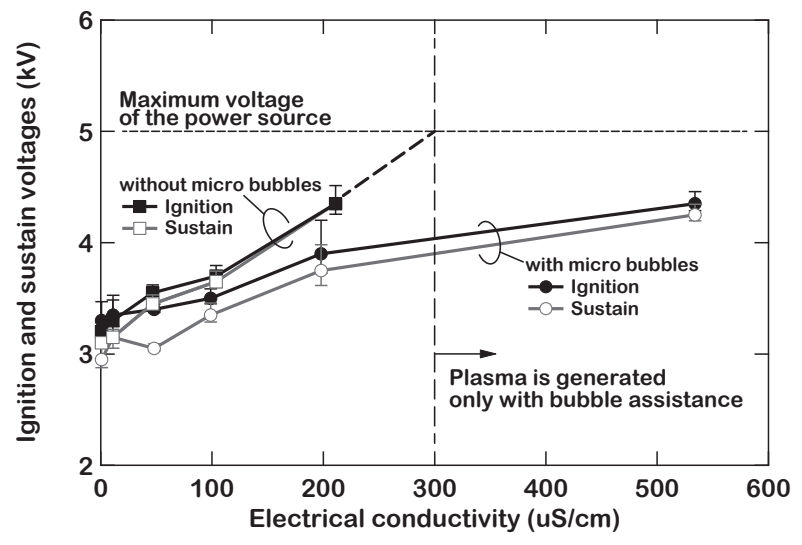

Fig. 11. Effects of micro bubbles on discharge ignition and sustain voltage of 3D IMSP.

$200 \mu \mathrm{S} / \mathrm{cm}$ を越えると放電開始が不可能となる。一方, マイクロバブルが有る場合には, $500 \mu \mathrm{S} / \mathrm{cm}$ まで放電が 可能となった。まだ $50 \mathrm{mS} / \mathrm{cm}$ の液体で放電できるとこ ろまで到達していないが，マイクロバブル援用法の最適 化や多孔質電極構造の最適化によって目標を達成したい と考えている。

なお，水の導電率が $200 \mu \mathrm{S} / \mathrm{cm}$ 以下であれば，バブ ルの有無に関わらず放電が可能である。そのようなとき の放電状態がマイクロバブルの有無によってどのように 異なるかを放電開始電圧と維持電圧を指標として調べ た。その結果を Fig. 11 に示す。同図から, マイクロバ ブルが有る場合の方が，若干ではあるが，放電開始電圧 と維持電圧が低く抑えられていることがわかる。これ は，同じ処理を行う際に，消費電力を抑制できる可能性 があることを示している。なお，こうしたマイクロバブ ル援用による放電開始電圧と維持電圧の低下は, ナノパ ルスを用いた水中放電においても観測されており，この 場合には, $10 \mathrm{kV}$ 程度の電圧低下が実現されている ${ }^{62)}$

\section{7. ナノ材料合成}

これまでの節では，プラズマから提供される破壊的な 因子が利用されていた。これに対し，建設的な因子を利 用することもできる。その一例として, 多くの研究者に よって報告されているナノ粒子の合成を挙げることがで きる ${ }^{63 \sim 69)}$ 。初期の頃は, $\mathrm{Au}, \mathrm{Ag}, \mathrm{Pt}$ などの還元されや すい金属のナノ粒子に関する報告が主であったが，その 後, 様々な電解質原料を用いることにより, 磁性材料や バイメタルのナノ粒子の合成に関する報告がなされてい

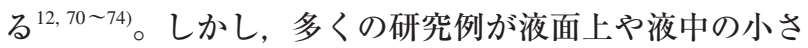
な放電を利用するものであり, 合成効率はあまりよくな いと考えられる。そこで筆者らは, 大容量化が可能な先 述の 3D IMSP による金ナノ粒子の合成を試みた 

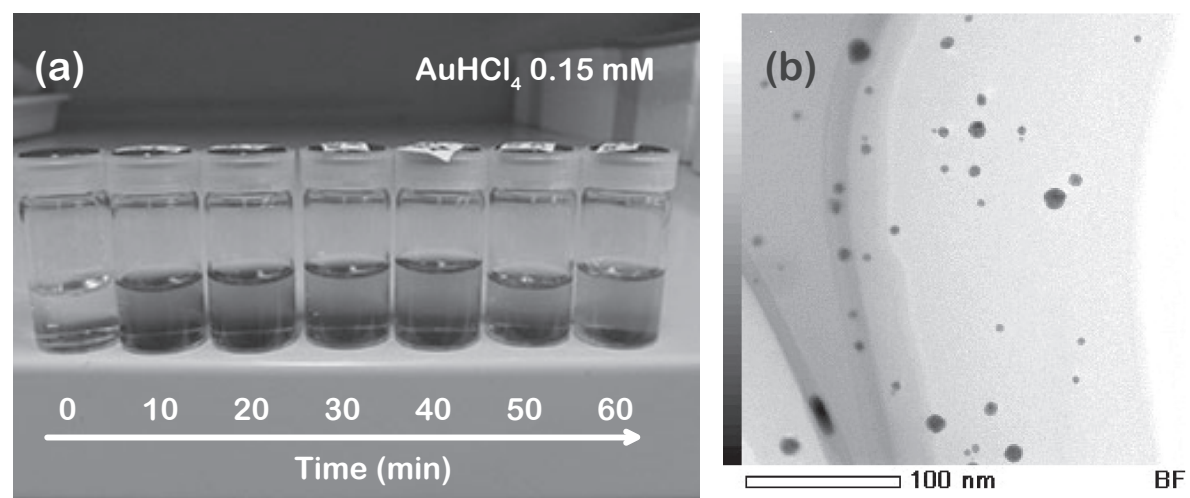

Fig. 12. (a) Time evolution of $\mathrm{HAuCl}_{4}$ aqueous solution treated with 3D IMSP. (b) A transmission electron microscope image of nanoparticles in aqueous solution after the treatment.

Fig. 12 (a) は, $\mathrm{HAuCl}_{4}$ 水溶液を 3D IMSP によって処 理した結果である。水溶液の色が処理時間とともに赤紫 色に変化して㧍り，金ナノ粒子を含むことを示してい る。また, Fig. 12（b）は, 得られた水溶液を乾燥した ものを透過電子顕微鏡にて観察した結果であり, ナノサ イズの粒子が形成されている。観測された粒子が金であ ることはエネルギー分散型 $\mathrm{X}$ 線分光によって確かめた。 残念ながら，ナノ粒子の粒径分散がかなり大きいが, 本 稿の最後の節で述べる手法を用いると，この分散の抑制 が可能となる。金属系のナノ粒子の合成は, 水溶液中で 電離している原料イオンが還元され，固体として析出す るというメカニズムで一般には説明されている。プラズ マを用いた場合には，液面と㓌極の間で放電したときに ナノ粒子が効率良く合成されることから，一般にはプラ ズマからの電子が還元反応に寄与しているとされてい $3^{68,69,75)}$ 。但し, 実験系によっては, 液面と陽極との間 の放電でもナノ粒子合成が可能であることが報告されて いる。この場合, 還元の担い手として, 水素原子, 水素 分子, 過酸化水素, 液中で二次的に発生する水和電子が 想定されている ${ }^{13,66,69) 。 ~}$

金属系ナノ粒子の合成は，溶液化学反応だけでも可能 であるため, プラズマを用いる場合には明確な付加価值 が必要となる。初期の頃は, 還元剂不要や高速合成とい う点がメリットとして挙げられていた。しかし，それだ けではメリットとして弱い。そのため, 近年では, プラ ズマで無ければ絶対にできないというメリットとして, 通常の溶液反応では極めて困難な組成のバイメタル等を 狙った研究が進められている ${ }^{73,74)}$

こうした金属系ナノ粒子以外にも，液中プラズマなら ではという特徴をつかんだ応用例として，SPを用いた 窒素ドープグラフェンの合成に関する取り組みがある。 窒素ドープグラフェンは, 燃料電池用触媒として注目さ
れているが，グラフェンのどこに窒素を入れても機能す るわけではない。触媒として機能させるためには, ピリ ジン型窒素と呼ばれる特定のサイトに窒素をドープする 必要がある。従来の窒素ドープは, 既にあるグラフェン に対して窒素をドープする。この場合，グラフェンの骨 格の一部を破壊しなければならないことや, 特定のサイ トに窒素ドープするのが困難という課題を有している。 これに対し, 石崎・齋藤等は, 原料としてベンゼン環の 中の所定の箇所に窒素が組み达まれている原料分子を用 いた SP プロセスにより，所望のドーピング状態を実現 しようとしている76)。

\section{8. 成膜とエッチング}

液体が関与する SP プロセスでは，これまでの節で紹 介してきたように，液体の浄化や液体中に分散したナ， 物質の合成, ナノ物質の表面処理のように, 液体中での 体積的なプロセスがほとんどである。これに対し，従来 のプラズマプロセスでよく知られている成膜4, 77 80) やエ ッチング1) などへの応用につながる報告例は極わずかし かない。

成膜応用に関しては，単純な還元反応による液面上で の金属䇴の析出がある。しかし, Gubkin が初めて銀簿 を析出した 1887 年以降4)，100 年以上を経ているにも関 わらず液面上でのプラズマ援用薄膜形成に関する報告例 がほとんど無い。これは, 研究者にとってそれが魅力的 でないからであろう。エッチング応用に関しては，レジ ストの超高速アッシングがマイクロ波励起の水中プラズ マによって実現されている ${ }^{81)}$

本節では，これまで報告例の無かったナノ粒子含有重 合薄膜という還元と重合が同時に起こるような系につい て紹介する。一般に，液中プラズマを用いたナノ粒子等 の合成プロセスでは，原料分子（もしくはイオン）を含 
む液中での放電をすることによって，還元または酸化の 過程を経てナノ粒子が合成される。金ナノ粒子合成の場 合には，水溶液中でイオン化している $\mathrm{HAuCl}_{4}$ が還元さ れて金ナノ粒子が合成されるとされている。その際，一 般には, 生成直後のナノ粒子の凝集防止のために保護剂

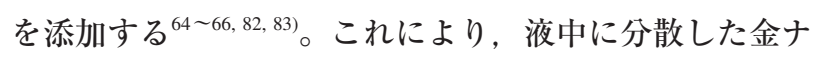
ノ粒子が合成される。

これに対し，筆者らは，プラズマとして「液中」では なく「液面上」での放電によるプラズマを用いた場合 に，液中に分散した金ナノ粒子が形成されるのではな く，金ナノ粒子が分散した保護剤由来の重合薄膜が液面 上に形成されることを見出した ${ }^{84)}$ 。現時点では, このよ うな薄膜の具体的用途を見いだせずにいるが，金ナノ粒 子が分散した生分解性重合膜は, ガン患部に付着して近 赤外レーザを照射することでガン治療に利用できること が報告されている ${ }^{85)}$

用いた気液界面リアクターの概念図を Fig. 13 に示す。 このリアクターは, 液体が片方の電極としての役割を担 う DBD 装置である。プラズマ処理の対象となる溶液 は, $0.3 \mathrm{mM}$ の $\mathrm{HAuCl}_{4}$ 水溶液 $75 \mathrm{~mL}$ と, 10 wt.\%のゼ ラチンを含んだ水溶液 $1.5 \mathrm{~mL}$ を混合した溶液である。 前者が金ナノ粒子の原料となり, 後者が薄膜の原料とな る。アルゴンを放電ガスとして液面上にプラズマを発生 させると, 上部電極の直下の液面上に紫色の薄膜が形成 される。その直径は, 放電時間とともに増加するが, 上 部電極の金属電極の直径程度で飽和する。10 分の放電 を終えた後の状態を Fig. 14 に示す。放電中の薄膜は, $\mathrm{DBD}$ 領域に捕獲されていることから, 何らかの静電的 な力で薄膜の位置が固定されていると考えている。ま た, 形成された薄膜の周辺の方が濃い色になっており, 中心部よりも周辺の方が厚いという特徽を有する。この 原因はまだ未解明であるが, 水平方向の直径増大という 成長様式がある時点で制限されると, 縦方向に成長せざ

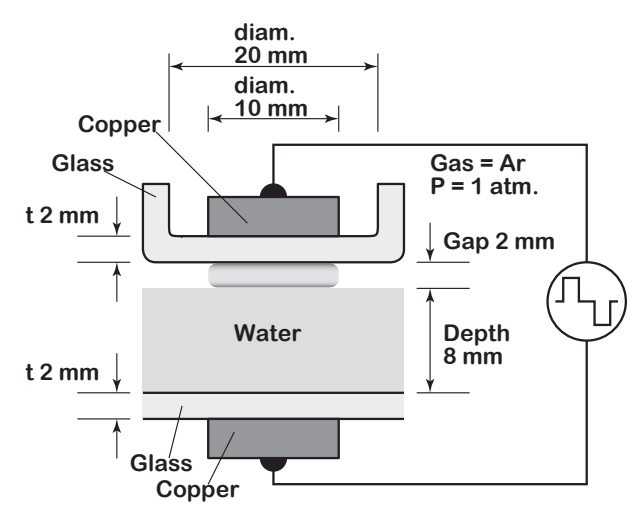

Fig. 13. Schematic diagram of the reactor to generate DBD on the liquid surface.

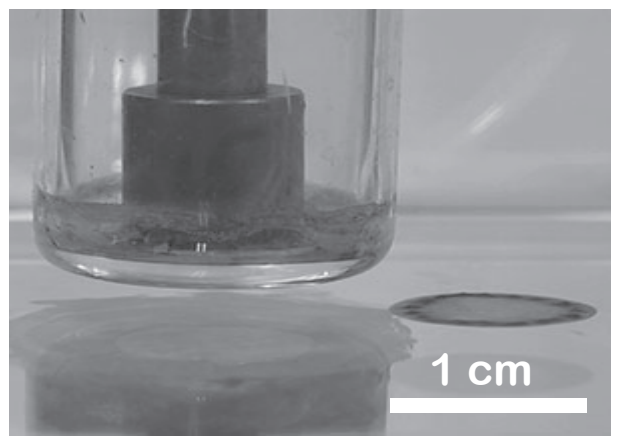

Fig. 14. A gold-nanoparticle-embedded film synthesized on the liquid surface.

るを得なくなるためではないかと考えている。

得られた膜は，ゼラチンが熱によってゲル化したもの とは異なっており, 架橋された湯葉のような状態であっ た。そのため, 分析の際には, ガラス基板やシリコン基 板ですくい上げたサンプルを分析した。そのサンプルを 紫外可視吸収分光, 赤外吸収分光, エネルギー分散型 X 線分光, および走查透過電子顕微鏡によって調べたとこ ろ，金ナノ粒子を含有するゼラチン重合体であることが わかった。

なお，この膜を走查透過電子顕微鏡で観測すると，異 なる二つのタイプの明視野像が得られる。一つは, ここ では示していないが, Fig. 12（b）とほぼ同等の粒径分 布の像であった。この結果は, 筆者らをかなり落胆させ た。なぜなら，液面上で薄膜にナノ粒子を埋め込むとい う面倒なことをする意義が全く無いからである。しかし， Fig. 15 のような明視野像も発見された。この写真から わかるように, イクラのように粒径の揃ったナノ粒子が アモルファスのマトリクス中にかなりの密度で捕獲され ている。この部分は, バックグラウンドがかなり濃いこ とから, アモルファス状の重合膜がかなり厚く成長した 部分ではないかと考えている。現時点では, 膜全体でこ

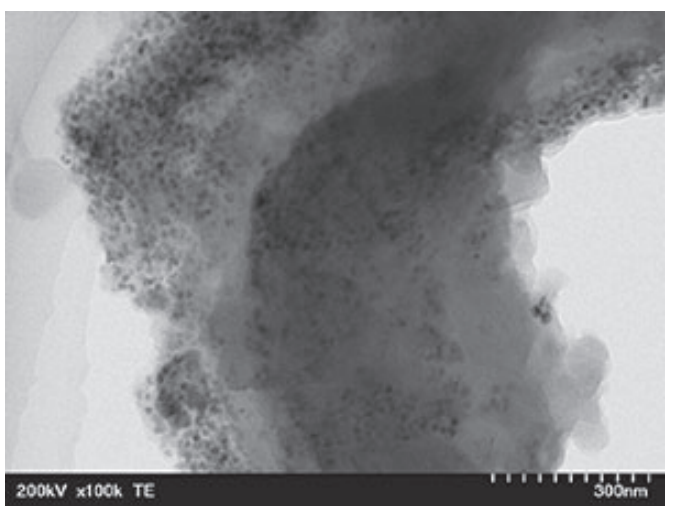

Fig. 15. A scanning transmission electron microscope image of a thin film with embedded gold nanoparticles. 


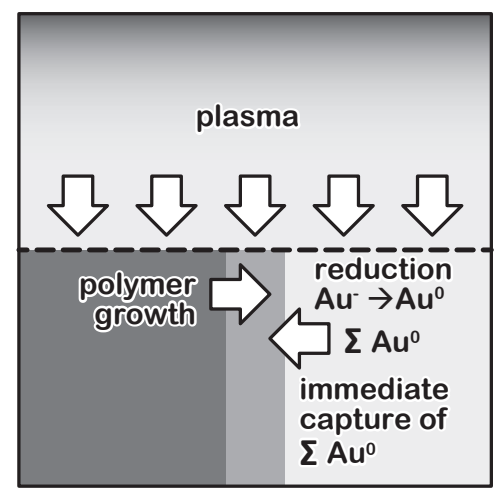

Fig. 16. A model to explain the size-regulation of gold nanoparticles embedded in a synthesized film.

のような状態にはなっていないが, 現在そのメカニズム を推定し，全域でこのようなことを引き起こすための方 策を検討中である。

Fig. 16 は現在検討中のメカニズムを示したものであ る。プラズマと接する液面直下では，ゼラチンの重合反 応による膜の成長と金イオンの還元によるナノ粒子形成 が同時進行している。膜成長のフロントエンドで還元生 成されたナノ粒子は，膜の成長によってすぐさま膜に捕 獲されることになる。捕獲されないナノ粒子もあると推 測されるが，プロセス中の液体の色は透明を維持してお り, 液体中に分散するナノ粒子の割合は極めて少ないと 考えている。な扔，同図では成膜中に顕著であった水平 方向の膜成長しか描かれていないが，垂直方向について も同様の機構が働くと考えている。膜に捕獲されるナノ 粒子の密度は, 還元速度と膜成長速度の兼ね合いで決ま り，それは液面に接するプラズマの特性によって左右さ れると考えられる。このメカニズムが正しければ，本稿 の冒頭で述べた「プラズマの状態がかなり顕著にプロセ ス結果に反映される」というプロセスが構築されたこと になる。部分的に Fig. 15 に示すような状況が生まれる 起源として，筆者らは局所的なストリーマ放電の寄与が 関係していると考えている。なお，今回のように膜形成 はされていないが，SPによるゼラチン重合に関する報 告例はあり，そこでは SP から供給される $\mathrm{OH}$ ラジカル が重合の担い手であるとされている ${ }^{86)}$ 。従って，還元反 応を支配する水素原子もしくは電子と, $\mathrm{OH}$ ラジカルの 寄与を制御することで膜質の制御ができるのではないか と考えている。

\section{9. を と め}

液体と接触したプラズマを用いる材料プロセスでは, プラズマはプラズマ/液体界面での一次過程を開始する トリガーとして重要な役割を果たす。このトリガーとし
ての直接的な影響は，液体全体に及ぶわけではなく，液 面直下の極めて薄い領域にしか及ばない。にも関わら ず，現在までに提案されている材料プロセスの多くは， プラズマ/液体界面を使うのではなく，むしろ，プラズ マの直接的な影響が届かないバルク液体の中の反応を利 用している場合が多い。このようにプラズマが単なるト リガーとなってしまっているにも関わらず，他の方法と の差別化が可能なのは，プラズマを用いることにより， 活性種をその場で効率良く生成できるからであると考え られる。一方，本稿の最後で紹介した液面上の薄膜形成 は，まさに液面直下だけを利用した材料プロセスとなっ ている。そこでは，ナノ粒子合成とその捕獲によるサイ ズ凍結という興味ある現象が示唆されており，これまで バルク液体中での反応が支配的であった液体関与プラズ マ材料プロセスの新しい可能性を拓くものではないかと 考えている。

\section{謝 辞}

本研究の一部は, 科学研究費補助金（課題番号 21110003，24540540，15H03585，15K13391）の助成金 を受けたものである。

\section{文献}

1) W. Elenbaas : "The High Pressure Mercury Vapour Discharge" (North Holland Pub. Co., Amsterdam, NL, 1951) Chap. 1.

2) N. Saito, J. Hieda, C. Miron and O. Takai : J. Surf. Finish. Soc. Jpn. 58, 810 (2007). (in Japanese).

3) M. Faraday : "Faraday's Diary. Being the Various Philosophical Notes of Experimental Investigation made by Michael Faraday. Vols. I-VII" (HR Direct, Riverton, UT, 2008).

4) J. Gubkin : Ann. Phys. 268, 114 (1887).

5) A.R. Denaro and A. Hickling : J. Electrochem. Soc. 105, 265 (1958).

6) A. Hickling and M.D. Ingram : Trans. Faraday Soc. 60, 783 (1964).

7) T. Cserfalvi, P. Mezei and P. Apai : J. Phys. D 26, 2184 (1993).

8) T. Cserfalvi and P. Mezei : Fresenius' J. Anal. Chem. 355, 813 (1996).

9) P. Mezei and T. Cserfalvi : Appl. Spectrosc. Rev. 42, 573 (2007)

10) P. Mezei and T. Cserfalvi : Sensors 12, 6576 (2012).

11) C. Richmonds, M. Witzke, B. Bartling, S.W. Lee, J. Wainright, C.-C. Liu and R.M. Sankaran : J. Am. Chem. Soc. 133, 17582 (2011).

12) N. Shirai, T. Yoshida, S. Uchida and F. Tochikubo : Jpn. J. Appl. Phys. 56, 076201 (2017).

13) N. Shirai, S. Uchida and F. Tochikubo : Jpn. J. Appl. Phys. 53, 046202 (2014). 
14) H. Kurafuji and K. Suda : Annals of the CIRP 16, 415 (1968).

15) R. Wüthrich : "Micromachining Using Electrochemical Discharge Phenomenon" (William Andrew, Oxford, UK, 2009) Chap. 1-2.

16) H. Hargitai and I. Rácz : "Polymer Composites Volume 1 : Macro- and Microcomposites" (Wiley-VCH, Weinheim, DE, 2012) Chap. 23.

17) H. Yang, Q. Zhang, M. Guo, C. Wang, R. Du and Q. Fu : Polym. 47, 2106 (2006).

18) J. Yang, J. Xiao, J. Zeng, L. Bian, C. Peng and F. Yang : Fibers Polym. 14, 759 (2013).

19) J. Hieda, T. Shirafuji, Y. Noguchi, N. Saito and O. Takai : J. Jpn. Inst. Met. Mater. 73, 938 (2009). (in Japanese)

20) T. Shirafuji, Y. Noguchi, T. Yamamoto, J. Hieda, N. Saito, O. Takai, A. Tsuchimoto, K. Nojima and Y. Okabe : Jpn. J. Appl. Phys. 52, 125101 (2013).

21) B.N. Khare, P. Wilhite, R.C. Quinn, B. Chen, R.H. Schingler, B. Tran, H. Imanaka, C.R. So, C.W. Bauschlicher, Jr. and M. Meyyappan : J. Phys. Chem. B 108, 8166 (2004).

22) G.X. Chen, H.S. Kim, B.H. Park and J.S. Yoon : Polymer 47, 4760 (2006).

23) Z. Špitalský, L. Matějka, M. Šlouf, E.N. Konyushenko, J. Kovárová, J. Zemek and J. Kotek : Polym. Compos. 30, 1378 (2009).

24) N. Takeuchi, M. Ando and K. Yasuoka : Jpn. J. Appl. Phys. 54, 116201 (2015).

25) K. Yasuoka, K. Sasaki and R. Hayashi : Plasma Sources Sci. Technol. 20, 034009 (2011).

26) H. Katayama, H. Honma, N. Nakagawa and K. Yasuoka : IEEE Trans. Plasma Sci. 37, 897 (2009).

27) P. Bruggeman and C. Leys : J. Phys. D 42, 053001 (2009).

28) T. Shirafuji, N. Saito, O. Takai, F. Tochikubo, K. Yasuoka, T. Kaneko, T. Ishijima, K. Takahashi, N. Takeuchi and N. Shirai : J. Surf. Sci. Soc. Jpn. 34, 547 (2013). (in Japanese).

29) T. Shirafuji and A. Nakamura : Trans. Mater. Res. Soc. Jpn. 38, 321 (2013).

30) T. Shirafuji, A. Nomura and Y. Himeno : Plasma Chem. Plasma Process. 34, 523 (2014).

31) T. Shirafuji and Y. Himeno : Jpn. J. Appl. Phys. 52, 11NE03 (2013).

32) T. Shirafuji, Y. Himeno, N. Saito and O. Takai : J. Photopolym. Sci. Technol. 26, 507 (2013).

33) A. Nomura, Y. Himeno, K. Tanaka and T. Shirafuji : Plasma Phys. Technol. 1, 147 (2014).

34) T. Shirafuji, Y. Ogura and Y. Himeno : Jpn. J. Appl. Phys. 53, 010211 (2014).

35) T. Shirafuji and T. Murakami : Jpn. J. Appl. Phys. 54, $01 \mathrm{AC} 03$ (2015).

36) Y. Himeno, Y. Ogura and T. Shirafuji : J. Phys. Conf. Ser. 518, 012021 (2014).

37) T. Shirafuji, Y. Ishida, A. Nomura, Y. Hayashi and M.
Goto : Jpn. J. Appl. Phys. 56, 06HF02 (2017).

38) T. Shirafuji, A. Nomura, Y. Hayashi, K. Tanaka and M. Goto : Jpn. J. Appl. Phys. 55, 01AH02 (2016).

39) A. Houas, H. Lachheb, M. Ksibi, E. Elaloui, C. Guillard and J.-M. Herrmann : Appl. Catal., B 31, 145 (2001).

40) R.G. Chaudhuri and S. Paria : Dalton Trans. 43, 5526 (2014).

41) H.J.H. Fenton : Proc. Chem. Soc. 9, 113 (1893).

42) H.J.H. Fenton : J. Chem. Soc. Trans. 65, 899 (1894).

43) E. Rosales, M. Pazos, M.A. Longo and M.A. Sanromán : Chem. Eng. J. 155, 62 (2009).

44) S. Ikawa, A. Tani, Y. Nakashima and K. Kitano : J. Phys. D 49, 425401 (2016).

45) P. Lukes, E. Dolezalova, I. Sisrova and M. Clupek : Plasma Sources Sci. Technol. 23, 015019 (2014).

46) H. Tanaka, M. Mizuno, K. Ishikawa, K. Takeda, K. Nakamura, F. Utsumi, H. Kajiyama, H. Kano, Y. Okazaki, S. Toyokuni, S. Maruyama, F. Kikkawa and M. Hori : IEEE Trans. Plasma Sci. 42, 3760 (2014).

47) T. Adachi, H. Tanaka, S. Nonomura, H. Hara, S. Kondo and M. Hori, Free Radical Biol. Med. 79, 28 (2015).

48) S. Elmore : Toxicol. Pathol. 35, 495 (2007).

49) G. Majno and I. Joris : Am. J. Pathol. 146, 3 (1995).

50) M. Schieber and N.S. Chandel : Curr. Biol. 24, R453 (2014).

51) J. Navarro-Yepes, M. Burns, A. Anandhan, O. Khalimonchuk, L.M. del Razo, B. Quintanilla-Vega, A. Pappa, M.I. Panayiotidis and R. Franco : Antioxid. Redox Signal. 21, 66 (2014).

52) W.P. Roos and B. Kaina : Cancer Lett. 332, 237 (2013).

53) W.P. Roos and B. Kaina : Trends Mol. Med. 12, 440 (2006).

54) B. Kaina : Biochem. Pharmacol. 66, 1547 (2003).

55) E. Stoffels, A.J.M. Roks and L.E. Deelman : Plasma Process. Polym. 5, 599 (2008).

56) I.E. Kieft, D. Darios, A.J.M. Roks and E. Stoffels : IEEE Trans. Plasma Sci. 33, 771 (2005).

57) J.M. Campos-Martin, G. Blanco-Brieva and J.L.G. Fierro : Angew. Chem., Int. Ed. 45, 6962 (2006).

58) J. Liu, B. He, Q. Chen, J. Li, Q. Xiong, G. Yue, X. Zhang, S. Yang, H. Liu and Q.H. Liu : Nature Sci. Rep. 6, 38454 (2016).

59) T. Shirafuji, J. Ueda, A. Nakamura, S.-P. Cho, N. Saito and O. Takai : Jpn. J. Appl. Phys. 52, 126202 (2013).

60) T. Imanaka : J. Environ. Biotechnol. 9, 65 (2009). (in Japanese).

61) T. Kanai, H. Imanaka, A. Nakajima, K. Uwamori, Y. Omori, T. Fukui, H. Atomi and T. Imanaka : J. Biotechnol. 116, 271 (2005).

62) K. Tachibana and T. Shirafuji : Trans. Mater. Res. Soc. Jpn. 35, 81 (2010).

63) C. Richmonds and R.M. Sankaran : Appl. Phys. Lett. 93, 131501 (2008). 
64) J. Hieda, N. Saito and O. Takai : J. Vac. Sci. Technol., A 26, 854 (2008).

65) N. Saito, J. Hieda and O. Takai : Thin Solid Films 518, 912 (2009).

66) M.A. Bratescu, S.-P. Cho, O. Takai and N. Saito : J. Phys. Chem. C 115, 24569 (2011).

67) Q. Chen, T. Kaneko and R. Hatakeyama : Chem. Phys. Lett. 521, 113 (2012).

68) R. Akolkar and R.M. Sankaran : J. Vac. Sci. Technol., A 31, 050811 (2013).

69) Q. Chen, J. Li and Y. Li : J. Phys. D 48, 424005 (2015).

70) M. Tokushige, A. Matsuura, T. Nishikiori and Y. Ito : J. Electrochem. Soc. 158, E21 (2011).

71) M. Tokushige, T. Nishikiori, M.C. Lafouresse, C. Michioka, K. Yoshimura, Y. Fukunaka and Y. Ito : Electrochim. Acta 55, 8154 (2010).

72) M. Tokushige, T. Nishikiori and Y. Ito : Russ. J. Electrochem. 46, 619 (2010).

73) Y.-G. Jo, S.-M. Kim, J.-W. Kim and S.-Y. Lee : J. Alloys Compd. 688, 447 (2016).

74) S.-M. Kim, A.-R. Cho and S.-Y. Lee : J. Nanopart. Res. 17, 284 (2015).

75) M. Tokushige, T. Yamanaka, A. Matsuura, T. Nishikiori and Y. Ito : IEEE Trans. Plasma Sci. 37, 1156 (2009).
76) G. Panomsuwan, S. Chiba, Y. Kaneko, N. Saito and T. Ishizaki : J. Mater. Chem. A 2, 18677 (2014).

77) J. Janek, M. Rohnke, M. Pöoleth and S.A. Meiss : "Electrodeposition from Ionic Liquids" (Wiley-VCH, Weinheim, 2008) Chap. 10, p. 259.

78) H. Furusho, D. Miyamoto, Y. Nagasaki, K. Kitano and S. Hamaguchi : J. Photopolym. Sci. Technol. 20, 229 (2007).

79) H. Furusho, K. Kitano, S. Hamaguchi and Y. Nagasaki : Chem. Mater. 21, 3526 (2009).

80) T.-J. Wu, C.-Y. Chou, C.-M. Hsu, C.-C. Hsu, J.-Z. Chen and I.-C. Cheng : RSC Adv. 5, 99654 (2015).

81) T. Ishijima, K. Nosaka, Y. Tanaka, Y. Uesugi, Y. Goto and H. Horibe : Appl. Phys. Lett. 103, 142101 (2013).

82) H. Heinz, C. Pramanik, O. Heinz, Y. Ding, R.K. Mishra, D. Marchon, R.J. Flatt, I. Estrela-Lopis, J. Llop, S. Moya and R.F. Ziolo : Surf. Sci. Rep. 72, 1 (2017).

83) M.C. Daniel and D. Astruc : Chem. Rev. 104, 293 (2004).

84) T. Shirafuji, Y. Nakamura, S. Azuma, N. Sotoda and T. Isshiki : Jpn. J. Appl. Phys. 57, 0102BE (2018).

85) A.K. Rengan, A.B. Bukhari, A. Pradhan, R. Malhotra, R. Banerjee, R. Srivastava and A. De : Nano Lett. 15, 842 (2015).

86) I. Prasertsung, S. Damrongsakkul and N. Saito : Plasma Process. Polym. 10, 792 (2013). 